\section{The Bible and Killing for Food}

\section{The Reverend Dr. Andrew Linzey Oxford University}

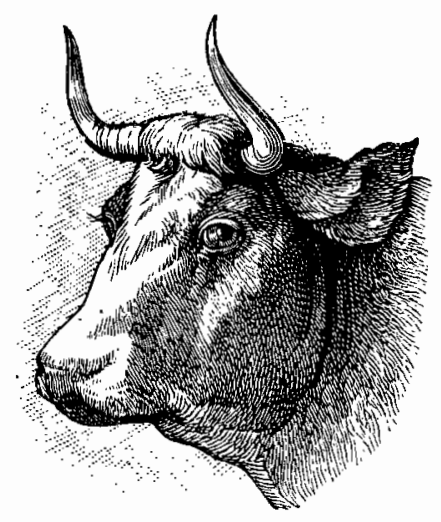

And God said, "Behold, I have given you every plant yielding seed which is upon the face of all the earth, and every tree with seed in its fruit; you shall have them for food. And to every beast of the earth, and to every bird of the air, and to everything that creeps on the earth, everything that has the breath of life, I have given every green plant for food." (Genesis 1:29-30; RSV).

And God blessed Noah and his sons, and said to them "...Every moving thing that lives shall be food for you; as I gave you the green plants, I give you everything." (Genesis 9:1-4; RSV).

At first glance, these two passages may be taken as epitomising the difficulty of appealing to scripture in the contemporary debate about animal rights. The sheer contradictoriness of these statements presses itself upon us. Genesis 1 clearly depicts vegetarianism as divine command. Indeed "everything" that has the breath of life in it, is given "green plant for food". Genesis 9, however, reverses this command quite specifically.

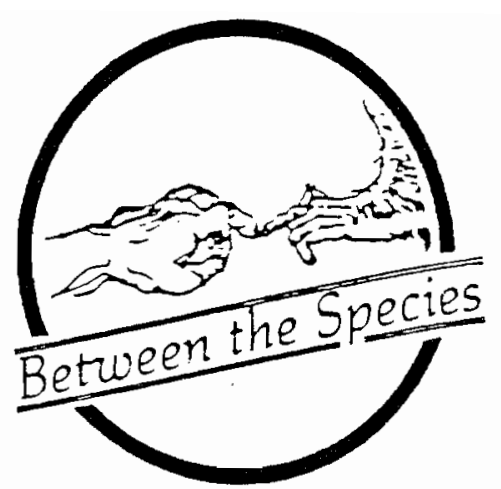

"(A)s I gave you the the green plants, I give you everything" (9:3). In the light of this, the question might not unreasonably be posed: Cannot both vegetarians and carnivores appeal to scripture for justification and both with equal support?

\section{Food of Paradise}

In order to unravel this conundrum we have first of all to appreciate that the community whose spokesperson wrote Genesis 1 were not themselves vegetarians. Few appreciate that Genesis 1 and 2 are themselves the products of much later reflection by the biblical writers themselves. How is it then that the very people who were not themselves vegetarian imagined a beginning of time when all who lived were vegetarian (herbivore to be precise) by divine command?

To appreciate this perspective we need to recall the major elements of the first creation saga. God creates a world of great diversity and fertility. Every living creature is given life and space (Gen. 1:9-10; 24-25), earth to live on and blessing to enable life itself (1:22). Living creatures are pronounced good (1:25). Humans are made in God's image (1:27), given dominion (1:26-29), and then prescribed a vegetarian diet (1:29-30). God then pronounces that everything was "very good" (1:31). Together the whole creation rests on the sabbath with God (2:2-3). When examined

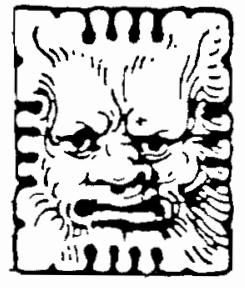

(C) Copyright A. Linzey, 1991

\section{RELIGION}


in this way, we should see immediately that Genesis 1 describes a state of paradisiacal existence. There is no hint of violence between or among different species. Dominion, so often interpreted as justifying killing, actually precedes the command to be vegetarian. Herbeating dominion is hardly a license for tyranny. The answer seems to be then that even though the early Hebrews were neither pacifists or vegetarians, they were deeply convinced of the view that violence between humans and animals, and indeed between animal species themselves, was not God's original will for creation.

But if this is true, how are we to reconcile Genesis 1 with Genesis 9, the vision of original peacefulness with the apparent legitimacy of killing for food? The answer seems to be that as the Hebrews began to construct the story of early human beginnings, they were struck by the prevalence and enormity of human wickedness. The stories of Adam and Eve, Cain and Abel, Noah and his descendants are testimonies to the inability of humankind to fulfil the providential purposes of God in creation. The issue is made explicit in the story of Noah:

Now the earth was corrupt in God's sight, and the earth was filled with violence. And God saw the earth, and behold, it was corrupt; for all flesh had corrupted their way upon the earth. And God said to Noah, "I have determined to make an end of all flesh; for the earth is filled with violence through them." (Gen. 6:11-14; RSV).

The radical message of the Noah story (so often overlooked by commentators) is that God would rather not have us be at all if we must be violent. It is violence itself within every part of creation that is the preeminent mark of corruption and sinfulness. It is not for nothing that God concludes that: "I am sorry that I have made them." (Gen. 6:7)

\section{Ambiguous Permission}

It is in this context-subsequent to the Fall and the Flood - that we need to understand the permission to kill for food in Genesis 9. It reflects entirely the situation of the biblical writers at the time they were writing. Killing - of both humans as well as animals-was simply inevitable given the world as it is and human nature as it is. Corruption and wickedness had made a mess of God's highest hopes for creation. There just had to be some accommodation to human sinfulness. "Every moving thing shall be food for you; and as I gave you the green plants, I give you everything." (Gen. 9:3). For many students of the Bible this seems to have settled the matter of whether humans can be justified in killing animals for food. In the end, it has been thought, God allows it. And there can be no doubt that throughout the centuries this view has prevailed. Meateating has become the norm. Vegetarians, especially Christian vegetarians, have survived from century to century to find themselves a rather beleaguered minority. The majority view can be summed up in this beautifully prosaic line of Calvin:

For it is an insupportable tyranny, when God, the Creator of all things, has laid open to us the earth and the air, in order that we may thence take food as from his storehouse, for these to be shut up from us by mortal man, who is not able to create even a snail or a fly. ${ }^{1}$

What Calvin appears to overlook, however, as has most of the Christian tradition, is that the permission to kill for food in Genesis 9 is far from unconditional or absolute:

Only you shall not eat flesh with its life, that is, its blood. For your lifeblood I will surely require a reckoning; of every beast I will require it and of man... (Gen. 1:4-5; RSV).

Understanding these lines is far from straightforward. At first sight these qualificatory lines might be seen as obliterating the permission itself. After all, who can take animal life without the shedding of blood? Who can kill without the taking of blood, that is, the life itself? In asking these questions we move to the heart of the problem. For the early Hebrews life was symbolised by, even constituted by, blood itself. To kill was to take blood. And yet it is precisely this permission which is denied.

It is not surprising then that commentators have simply passed over these verses suggesting that some ritual, symbolic significance was here entertained but one which in no way substantially affected the divine allowance to kill. But this, I suggest, is to minimise the significance of these verses. Rereading these verses in 
the light of their original context should go rather like this: The world in which you live has been corrupted. And yet God has not given up on you. God has signified a new relationship-a covenant with you-despite all your violence and unworthiness. Part of this covenant involves a new regulation concerning diet. What was previously forbidden can now-in the present circumstances - be allowed. You may kill for food. But you may kill only on the understanding that you remember that the life you kill is not your own--it belongs to God. You must not misappropriate what is not your own. As you kill what is not your owneither animal or human life-so you need to remember that for every life you kill you are personally accountable to God. ${ }^{2}$

If this reading is correct, and I believe few scholars would now dissent from this interpretation, it will be seen immediately that Genesis 9 does not grant humankind some absolute right to kill animals for food. Indeed, properly speaking, there is no right to kill. God allows it only under the conditions of necessity. Arecent statement by the Union of Liberal and Progressive Synagogues expresses it this way: "Only after the Flood (contends Genesis 9:3) was human consumption of animals permitted and that was later understood as a concession, both to human weakness and to the supposed scarcity of edible vegetation."3

To give a more complete account of biblical themes requires us to move on from Genesis 1 and 2 , to Isaiah 11 . We need to appreciate that while killing was sometimes thought to be justifiable in the present time, biblical writers were also insistent that there would come another time when such killing was unnecessary. This is the time variously known as the "future hope of Israel" or the "Messianic Age". Isaiah speaks of the one who will establish justice and equity and universal peace. One of the characteristics of this future age is the return to the existence envisaged by Genesis 1 before the Fall and the Flood:

The wolf shall dwell with the lamb, and the leopard shall lie down with the kid, and the calf and the lion and the fatling together, and a little child shall lead them. The cow and the bear shall feed; their young shall lie down together; and the lion shall eat straw like the ox. The sucking child shall play over the hole of the asp, and the weaned child shall put his hand on the adder's den. They shall not hurt or destroy in all my holy mountain; for the earth shall be full of the knowledge of the Lord as the waters cover the sea. (Isaiah 11:6-9; RSV).

It seems therefore that while the early Hebrews were neither vegetarians nor pacifists, the ideal of the peaceable kingdom was never lost sight of. In the end, it was believed, the world would one day be restored according to God's original will for all creation. Note, for example, how the vision of peaceable living also extends to relations between animals themselves. Not only, it seems, are humans to live peaceably with animals, but also formerly aggressive animals are to live peaceably with other animals.

We may sum up the main elements of the biblical approach as follows: Killing for food appears essential in the world as we now know it, influenced as it is by corruption and wickedness. But such a state of affairs is not as God originally willed it. Even when we kill under situations of necessity we have to remember that the lives we kill do not belong to us and that we are accountable to God. Moreover, God's ultimate will for creation shall prevail. Whatever the present circumstances, one day all creation, human and animal, shall live in peace.

\section{Living Without Violence}

It should now be seen that far from being confused and contradictory, the biblical perspectives on killing for food have not only internal integrity but also enormous relevance to the contemporary debate about animal rights and vegetarianism. There are three ethical challenges in particular that we should grapple with.

The first thing that should be noted is that the Bible does not minimise the gravity of the act of killing animals. So often in our heavily industrialised societies we think of animals, especially farm animals, as merely food machines or commodities that are to be bought or sold for human consumption. This can never be the biblical view. Genesis 1 specifically speaks of animal life as that which "has the breath of life" (1:30). This life is a gift from God. It does not belong to human beings. It may be used only with the greatest reserve and in remembrance of the One from whose creative hands it comes. Those who wish to use animals frivolously or with no regard for their God-given worth cannot claim the Bible for their support. 
Karl Barth is instructive on this point and deserves to be read in full:

If there is a freedom of man to kill animals, this signifies in any case the adoption of a qualified and in some sense enhanced responsibility. If that of his lordship over the living beast is serious enough, it takes on a new gravity when he sees himself compelled to express his lordship by depriving it of its life. He obviously cannot do this except under the pressure of necessity. Far less than all the other things which he dares to do in relation to animals, may this be ventured unthinkingly and as though it were self-evident. He must never treat this need for defensive and offensive action against the animal world as a natural one, nor include it as a normal element in his thinking or conduct. He must always shrink from this possibility even when he makes use of it. It always contains the sharp counter-question: Who are you, man, to claim that you must venture this to maintain, support, enrich and beautify your own life? What is there in your life that you feel compelled to take this aggressive step in its favour? We cannot but be reminded of the perversion from which the whole historical existence of the creature suffers and the guilt of which does not really reside in the beast but ultimately in man himself. ${ }^{4}$

The second challenge is that we have no biblical warrant for claiming killing as God's will. God's will is for peace. We need to remember that even though Genesis 9 gives permission to kill for food it does so only on the basis that we do not misappropriate Godgiven life. Genesis 9 posits divine reckoning for the life of every beast taken even under this new dispensation (9:5). The question may not unnaturally be asked: How long can this divine permission last? Karl Barth writes that "it is not only understandable but necessary that the affirmation of this whole possibility ( of killing for food) should always have been accompanied by a radical protest against it." And yet he concludes: "It may well be objected against a vegetarianism which presses in this direction that it represents a wanton anticipation of what is described by Is. 11 and Rom. 8 as existence in the new aeon for which we hope." ${ }^{5}$ Whatever may be the merits of Barth's arguments here, it should be clear that Barth cannot and does not claim that killing is God's will. On the contrary it stands in direct contrast to the "new aeon for which we hope" or, as he puts it elsewhere, "under a caveat." In short: even though killing may be sometimes permissible, God will not tolerate it forever.

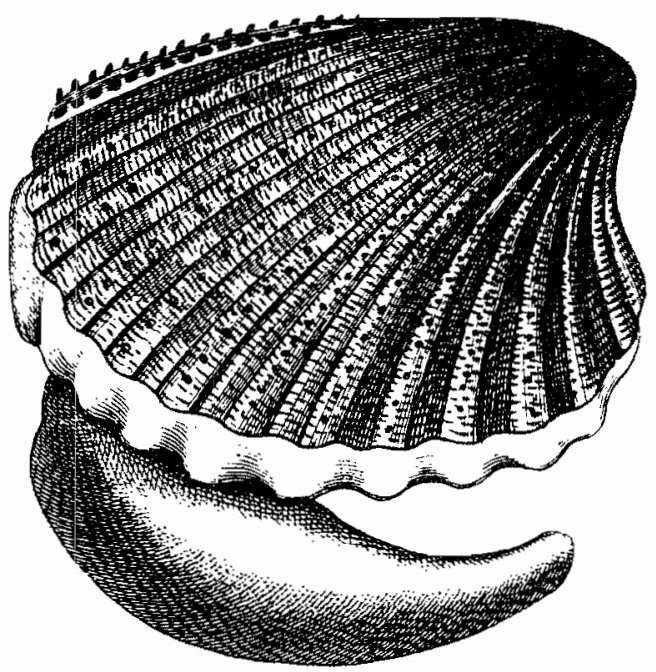

In this respect it is interesting that one highly regarded Talmudic scholar, Abraham Isaac Kook, maintains that the most spiritually satisfying way of reading the practical biblical injunctions concerning killing is in terms of preparation for a new dawn of justice for animals. "The free movement of the moral impulse to establish justice for animals generally and the claim for their rights from mankind," he argues, "are hidden in a natural psychic sensibility in the deeper layers of the Torah." Given the corruption of humankind, it was natural and inevitable that moral attention had first to be paid to the regulation of human conduct towards other humans. But in Kook's view the various injunctions concerning the selection and preparation of meat (in for example Lev. 17:13; Ezek. 16:63, Lev. 22:28 and Deut. 22:26-27) were commandments "to regulate the eating of meat, in steps that will take us to the higher purpose." And what is this higher purpose? None other it seems than universal peace and justice. 
Kook maintains that just as the embracing of democratic ideals came late within religious thinking "so will the hidden yearning to act justly towards animals emerge at the proper time."7

The third challenge to be grasped is that those who wish now to adopt a vegetarian or vegan lifestyle have solid biblical support. Biblical vegetarians will not say, "It has never been justifiable to kill animals", rather they should say, "It is not now necessary to kill for food as it was once thought necessary." The biblical case for vegetarianism does not rest on the view that killing may never be allowable in the eyes of God, rather on the view that killing is always a grave matter. When we have to kill to live we may do so, but when we do not, we should live otherwise. It is vital to appreciate the force of this argument. In past ages many--including undoubtedly the biblical writers themselves-have thought that killing for food was essential in order to live. We now know that-at least for those now living in the rich West-it is perfectly possible to sustain a healthy diet without any recourse to flesh products. This may not have always been true in the past. Conventional wisdom was always that meat was essential to live and to live well. Only during the past 200 years has vegetarianism become a publicly known and acceptable option.

Those individuals who opt for vegetarianism can do so in the knowledge that they are living closer to the biblical ideal of peaceableness than their carnivorous contemporaries. The point should not be minimised. In many ways it is difficult to know how we can live more peaceably in a world striven by violence and greed and consumerism. Individuals often feel powerless in the face of great social forces beyond even democratic control. To opt for a vegetarian lifestyle is to take one practical step towards living in peace with the rest of creation. It has been estimated that over 500 million animals are slaughtered for food in the UK every year. In the US the numbers are 6-9 billion annually. To become vegetarian is to take a practical step to reduce the rate of institutionalised killing in the world today. One less chicken eaten is one less chicken killed.

Nevertheless, we do well to appreciate the biblical perspective that we do not live in an ideal world. The truth is that even if we adopt a vegetarian or vegan lifestyle, we are still not free of killing either directly or indirectly. Even if we only eat beans and nuts and lentils, we have to reckon with the fact that competing animals are killed because of the crops we want to eat. Even if we decide not to wear dead animal skins, we have to face the fact that alternative substances have been tested for their toxicity on laboratory animals. Even if we only eat soya beans we do well to remember that these have been force fed to animals in painful experiments. As I have written elsewhere, there is no pure land. ${ }^{8}$ If we embark on vegetarianism, as I think we should, we must do so on the understanding that for all its compelling logic, it is only one small step towards the vision of a peaceful world.

\section{Prince of Peace}

Before I conclude, there is one major-and some would say conclusive-objection to my pro-vegetarian thesis that should be considered. It is this: Jesus was no vegan and possibly no vegetarian. There are no recorded examples of Jesus eating meat in the Gospels. The only possible exception is the Passover itself, but it is not clear to say the least that Jesus ate the traditional passover meal. Jesus did, however, eat fish if the Gospel narratives are to be believed. How are we to reconcile this to the established Christian view of Jesus as the Prince of Peace? There are four possible answers to this question.

The first is that the canonical gospels are mistaken and Jesus was actually a vegetarian. However implausible this view may appear, among those who are pro-animals there have always been a significant number who have never believed that Jesus ate the flesh of other living creatures. ${ }^{9}$ Those who take this view argue that "fish" in the New Testament did not actually mean fish as we know it today. Moreover it is sometimes argued that Jesus was really a member of the Essene sect who were, it seems, strict vegetarians. Indeed there are various "Essene gospels" in which Jesus is depicted as a committed vegetarian. ${ }^{10} \mathrm{On}$ the face of it, it does seem highly unlikely that such a convenient view is true and the Essene gospels strike me as of rather doubtful antiquity. Nevertheless, I would like to keep an open mind. It is just conceivable that some of these gospels do somehow contain genuine historical reminiscences (we know so little about the historical Jesus in any case) but I think it is a rather remote possibility.

The second possible answer is that Jesus was not perfect in every conceivable way. Jews and Muslims would, of course, have no difficulty with this proposition 
but orthodox Christians would surely find this idea difficult. After all traditional Christian belief has always been that Jesus Christ was truly God and truly man. Most Christians would hold that being sinless was an essential part of being God incarnate. Those who argue that Jesus was not wholly perfect, however, are not, of course, wholly without biblical support. The question of Jesus: "Why do you call me good?" And his answer: "No one is good but God alone" is recorded in all three synoptic gospels (Luke 18:19; Matthew 19:17; Mark 10:18). Moreover, it is not inconceivable that Jesus could have been both God incarnate and less than morally perfect in every way. Some scholars, such as John Robinson, have maintained this. ${ }^{11}$ Perhaps it could be argued that while Jesus committed no sin of commission (deliberate wrongdoing), of necessity every human being commits some sin of omission (things left undone). However, such a view certainly falls short of traditional Christian doctrine and biblical texts such as Hebrews 4:15 which argues that Jesus "was tempted as we are, yet without sin."

The third answer is that the killing of fish is not a morally significant matter or, at least, not as significant as the killing of mammals. There is something to be said for this view. Even those who argue rigorously for animal rights sometimes do so on the basis that animals as God's creatures are "subjects of a life"that is they have sensitivity and consciousness and the ability to suffer-but it is not clear that all fish do actually possess all these characteristics. In many cases we simply do not know. This must mean, I think, that their moral status is somewhat different from those animals where self-consciousness and sentiency can reasonably be taken for granted. Nevertheless, do not fish merit some benefit of the doubt? Are they not also fellow creatures with some God-given life and individuality which means that wherever possible their lives should be respected?

The fourth answer is that sometimes it can be justifiable to kill fish for food in situations of necessity. Such a situation, we may assume, was present in first century Palestine where geographical factors alone seem to have suggested a scarcity of protein. Such a view would on the whole be more consistent with the biblical perspective that we may kill but only in circumstances of real need. Hence we may have to face the possibility that Jesus did indeed participate in the killing of some life forms in order to live. Indeed we may say that part of his being a human being at a particular stage and time in history necessitated that response in order to have lived at all.

Of all the four possible responses, I find this last one the most convincing. As I have indicated before, the biblical view is not that killing can never be justified and ought to be avoided at all costs. There are times, for example, when euthanasia may well be the most compassionate response to an individual being undergoing unrelievable suffering. But even if we accept that killing for food may be justified in those situations of real necessity for human survival, such as may be argued in the case of Jesus himself, this in no way exonerates us from the burden of justifying what we now do to animals in circumstances substantially different. This last point is centrally important and must not be obscured. There may have been times in the past or even now in the present where we have difficulty imagining a life without killing for food. But where we do have the moral freedom to live without killing, without recourse to violence, there is a prima facie case that we should do so. To kill without the strict conditions of necessity is to live a life with insufficient generosity.

It would be wrong, however, to give the impression that the life and teaching of Jesus is a disappointment as far as the enlightened treatment of animals is concerned. While it is true that there is a great deal we do not know about Jesus' precise attitudes to animals, there is a powerful strand in his ethical teaching about the primacy of mercy to the weak, the powerless and the oppressed. Without misappropriation, it is legitimate to ask: Who is more deserving of this special compassion than the animals commonly exploited in our world today? Moreover, it is often overlooked that in the canonical gospels Jesus is frequently presented as identifying himself with the world of animals. As I have written elsewhere:

His birth, if tradition is to be believed, takes place in the home of sheep and oxen. His ministry begins, according to Mark, in the wilderness "with the wild beasts" (1:13). His triumphal entry into Jerusalem involves riding on a "humble ass" (see Matthew 21:b-5). According to Jesus it is lawful to "do good" on the Sabbath, which includes the rescuing of an animal fallen into a pit (see Matthew $12: 10 \mathrm{~b}-12$ ). Even the sparrows, literally sold for a few pennies in his day, are not "forgotten before God". God's providence extends to the 
entire created order, and the glory of Solomon and all his works cannot be compared to that of the lilies of the field (Luke 12:27). God so cares for his creation that even "foxes have holes, and birds of the air have nests, but the Son of man has nowhere to lay his head." (Luke 9:58). ${ }^{12}$

The significance of these and other verses may be much more than had previously been thought. One small example must suffice. Mark describes Jesus' ministry as taking place firstly within the context of wild animals (1:13). Richard Bauckham has recently argued that the context in which this verse should be understood is messianic in orientation. Jesus is shown to be in continuity with the Isaianic tradition in seeing the messianic age as bringing about a reconciliation between nature and humanity. ${ }^{13}$ If this is true, it may be that Mark is seeking to demonstrate how the Gospel of Jesus has implications for the whole of the created world and harmony within the animal world in particular. Those who follow Jesus might argue that in seeking to realise what can now be realised in our own time and space of the messianic age is to live now in conformity with the Spirit of Jesus itself.

In conclusion, reference has already been made to how vegetarians have formed a rather beleagued minority in times past. But it is worth recalling that not a few of the great figures in Christendom have adopted a vegetarian diet. Among these should not go unnoticed the countless saints who have expressed a particular regard for animals and opposed their destruction. "Poor innocent little creatures," exclaimed St. Richard of Chichester when confronted with animals bound for slaughter. "If you were reasoning beings and could speak you would curse us. For we are the cause of your death, and what have you done to deserve it?"14 There has always been an ascetical strand within Christianity which has insisted that humans should live gently on the earth and avoid luxury food. The rule of life penned by St. Benedict for his religious community, for example, expressly forbade the eating of meat. "Except the sick who are very weak, let all abstain entirely from the flesh of four-footed animals." ${ }^{15}$ Moreover, it often comes as a surprise for Christians to realise that the modern vegetarian movement was strongly biblical in origin. Inspired by the original command in Genesis 1 , an Anglican priest, William Cowherd, founded the Bible Christian Church in 1809 and made vegetarianism compulsory amongst its members. The founding of this church in the United Kingdom and its sister church in the United States by William Metcalfe, effectively heralded the beginning of the modern vegetarian movement. ${ }^{16}$

The subsequent, if rather slow, growth of vegetarianism from 1809 to 1970 , and its rapid and astonishing growth from 1970 to the present day is testimony that Cowherd may have been right in his view that mainstream biblical theology had overlooked something of importance in Genesis 1 . It may be that when the history of twentieth century cuisine is finally written, the radical changes in diet which we are currently experiencing will be found to be due more to the rediscovery of two biblical verses (Genesis 1:29-30) than anything else. These two verses, we may recall, came into existence by people imagining possibilities in the light of their belief in God the Creator. By rekindling the same vision in our own time, we may be enabled to realise - at least in part-those possibilities which our forebears could only imagine. Forward, we may say, not backward to Genesis.

\section{Chapter of Using the Bible Today edited by Dan Cohn-Sherbok Bellew Publishing, 1991 \\ Notes}

${ }^{1}$ John Calvin, Commentaries on the First Book of Moses, vol. 1, ET by John King (Edinburgh: Calvin Translation Society, 1847), pp. 291 f. Extract in Andrew Linzey and Tom Regan (eds) Animals and Christianity: $A$ Book of Readings (London: SPCK and New York: Crossroad, 1989), pp. 199-200.

${ }^{2}$ This argument is developed at length in Andrew Linzey, Christianity and the Rights of Animals (London: SPCK and New York: Crossroad, 1987), especially pp. 141-149.

${ }^{3}$ Where We Stand on Animal Welfare (London: Rabbinic Conference of the Union of Liberal and Progressive Synagogues, May 1990), p. 1.

${ }^{4}$ Karl Barth, Church Dogmatics, Vol. III, part 4, The Doctrine of Creation, ET by A. T. Mackay, T. H. L. Parker, H. Knight, H. A. Kennedy and J. Marks (Edinburgh: T. and T. Clark, 1961), p. 352; extract in Animals and Christianity, ibid, pp. 191-193.

\footnotetext{
${ }^{5}$ Barth, ibid, p. 353 n.

${ }^{6}$ Barth, ibid, p. 354.
} 
${ }^{7}$ Abraham Isaac Kook, The Lights of Penitence, The Moral Principles, Lights of Holiness, Essays, Letters, and Poems, ET by B. Z. Bokser, preface by J. Agus and R. Schatz, The Classics of Western Spirituality (London: SPCK, 1979), pp. 317-323. I am grateful to Jonathan Sacks for this reference.

${ }^{8}$ See inter alia Christianity and the Rights of Animals, ibid, p. 148.

${ }^{9}$ See, e.g., Geoffrey L. Rudd, Why Kill for Food? (Cheshire: The Vegetarian Society, 1970), pp. 78-90, and Steven Rosen, Food for the Spirit: Vegetarianism and the World Religions (New York: Bala Books, 1987), pp. 33-39.

${ }^{10}$ For example, The Gospel of the Holy Twelve and The Essene Humane Gospel of Jesus, cited and discussed in Rosen, ibid.

11 J. A. T. Robinson, "Need Jesus have been Perfect?" in S. W. Sykes and J. P. Clayton (eds) Christ, Faith and History, Cambridge Studies in Christology (Cambridge: CUP, 1972), pp. 39-52.
12 "Introduction" to Andrew Linzey and Tom Regan (eds) Compassion for Animals: Readings and Prayers (London: SPCK, 1989), p. xv.

${ }^{13}$ I am grateful to Richard Bauckham for his recent lecture at Essex University on this theme and for bringing to my attention the significance of this verse. I understand that his work will shortly be published as Jesus and the Greening of Christianity.

${ }^{14}$ St. Richard of Chichester, cited in Butler's Lives of the Saints, also extract in Compassion for Animals: Readings and Prayers, ibid, p. 66.

15 The Rule of St Benedict, ET by Justin McCann, Spiritual Masters Series (London: Sheed and Ward, 1976), chp. 39 , p. 46.

${ }^{16}$ See Richard D. Ryder, Animal Revolution: Changing Attitudes Towards Speciesism (Oxford: Blackwells, 1989), p. 96. For a history of the Church in America see The History of the Philadelphia Bible-Christian Church. 1817-1917 (Philadelphia:J. B. Lippincott Company, 1922). I am grateful to Bernard Unti for this last reference.

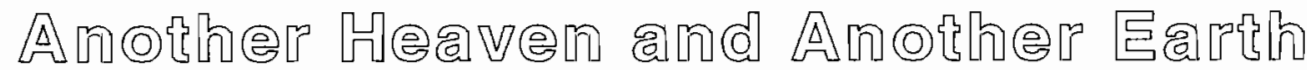

I would like you to know

That we were not all like that.

That some of us spent our lives

Working for Peace

Speaking for animals

Tending the Earth.

And that when you find

The mass graves

And the abattoirs

And the laboratories

Please understand

That we were not all like that.

Mary de La Valette 